\title{
PROGRAM BACA TULIS ASIK, KREATIF DAN KOMUNIKATIF DI SEKOLAH DASAR
}

\author{
Titis Angga Rini \\ Jurusan KSDP FIP Universitas Negeri Malang \\ Jalan Semarang No. 5 Malang. \\ Email: angga.rini.fip@um.ac.id
}

\begin{abstract}
The purpose of this study is to develop a reading and writing program in elementary schools to foster awareness and interest in student literacy. This program was developed based on PjBL (Project Based Learning) as an ongoing activity. This program was developed through five stages with (1) analysis, (2) planning, (3) development, (4) application, and (5) evaluation. The research data collected by questionnaires, interviews, and observation instruments that analyzed by qualitative descriptive techniques. The results of the program development show that this programs can be applied in elementary schools with qualifications in terms of practicality, attractiveness, and program usefulness.
\end{abstract}

Keywords: literacy skill, elementary school, writing and reading program

\begin{abstract}
Abstrak: Tujuan penelitian ini adalah untuk mengembangkan dan menerapkan program Baca Tulis Asik, Kreatif, dan Komunikatif di SD untuk menumbuhkan kesadaran dan minat literasi siswa. Program dikembangan berbasis PjBL sebagai kegiatan yang diterapkan secara berkelanjutan. Program dikembangkan melalui lima tahap penelitian pengembangan yang terdiri dari (1) analisis, (2) perencanaan, (3) pengembangan, (4) penerapan, dan (5) evaluasi. Data hasil penelitian dikumpulkan dengan instrumen angket, wawancara, dan observasi yang dianalisis dengan teknik deskriptif kualitatif. Hasil pengembangan program menunjukkan bahwa program baca tulis dapat diterapkan di sekolah dasar dan menunjukkan kualifikasi dari segi kepraktisan, kemenarikan, dan kebermanfaatan program.
\end{abstract}

Kata Kunci: keterampilan literasi, sekolah dasar, program baca tulis

Keterampilan membaca dan menulis memegang peran penting dalam proses belajar dan mengajar di sekolah berkaitan dengan kemampuan literasi. Keterampilan siswa dalam membaca dan menulis akan berpengaruh terhadap kemampuannya dalam menerima dan mengolah informasi dalam sebuah teks. Studi terhadap PIRLS 2011 menunjukan bahwa rata-rata kemampuan siswa Indonesia berada pada peringkat 45 dari 48 negara peserta. Hal ini menunjukkan bahwa keterampilan literasi membaca dan menulis siswa masih berada di bawah rata-rata dan perlu ditingkatkan. Rendahnya keterampilan literasi membaca siswa menurut hasil Suryaman (2011) tentang analisis keterampilan literasi siswa berdasarkan hasil PIRLS 2011 disebabkan ka- rena pengembangan kompetensi membaca siswa kurang maksimal. Berkaitan dengan hasil penelitian tersebut sebagai keterampilan bahasa tulis maka rendahnya keterampilan membaca ini juga berpengaruh terhadap keterampilan siswa dalam menulis

Untuk mengetahui keterampilan literasi membaca dan menulis, dilakukan studi pendahuluan di kelas III SDN Karangbesuki 02 Kota Blitar. Kesimpulan dari hasil observasi dan wawancara menunjukkan bahwa (1) keterbatasan media dan sumber belajar yang digunakan dalam kegiatan pembelajaran, khususnya yang berkaitan dengan kegiatan membaca dan menulis, membuat siswa kurang terlatih dalam mengembangkan keterampilan membaca dan menulis; (2) belum adanya program baca 
tulis khusus yang membimbing siswa giat membaca segala bacaan dan menuliskan gagasan siswa; (3) belum adanya apresiasi terhadap hasil karya tulisan siswa; (4) ditinjau dari manfaat membaca dan menulis bagi siswa, jika dikaitkan dengan data hasil observasi dan wawancara yang ditemukan, dirasa perlu adanya upayauntuk mengembangkan kemampuan membaca dan menulis siswa yang dapat mendorong dan membimbing siswa memiliki kebiasaan dan minatdalam membaca dan menulis dengan baik.

Berdasarkan hasil studi pendahuluan, untuk mengembangkan keterampilan literasi siswa dalam membaca dan menulis peneliti merancangkan sebuah program yang dapat diterapkan dalam kegiatan membaca dan menulis di sekolah dasar. Perancangan program akan disesuaikan dengan implementasi kebijakan GLS di SD yang difokuskan pada kemampuan siswa dalam mengakses, memahami, dan menggunakan sesuatu secara cerdas melalui berbagai aktivitas berbahasa (Kemendikbud, 2016:2). Program didefinisikan sebagai hubungan makna yang dirancang dan diterapkan dengan tujuan tertentu yang terdiri dari sekelompok aktivitas yang dimaksudkan untuk mencapai satu atau terkait tujuan yang akan dicapai (McDavid \& Hawthorn, 2009: 15). Program baca tulis ini dikembangkan mengacu pada Project Based Learning (PjBL). Project Based Learning merupakan salah satu model belajar yang dapat mendorong pengkonstruksian pengetahuan dan keterampilan siswa secara bekelanjutan (Sani, 2013:171). Melaui PjBL diharapkan program kegiatan membaca dan menulis dapat dilaksanakan secara berkelanjutan sebagai sebuah proyek dalam kelas yang melibatkan keterampilan membaca dan menulis siswa.

Keterlibatan siswa secara melalui PBL ditujukan agar kegiatan membaca dan menulis menjadi sebuah rutinitas yang dapat membangun kebiasaan literasi siswa. Penelitian sebelumnya oleh Bilgin, Kurakuyu, \& Ay (2015) menunjukkan bahwa PBL berpengaruh positif terhadap hasil belajar dan self efficacy siswa melalui pengalaman yang diperoleh selama kegiatan proyek. Khusus pada desain program, kegiatan proyek diwujudkan melalui kegiatan baca tulis yang terintegrasi berbasis proses sehingga keterampilan siswa dapat diketahui dan dikembangkan untuk membangun kebiasaan literasi dengan lebih baik. Hal ini sesuai dengan hasil penelitian sebelumnya oleh Ahmed, Wagner, \& Lopez (2014) bahwa model membaca dan menulis efektif ditera- pkan jika dapat menggambarkan tingkat berbahasa yang mampu dicapai siswa. Berdasarkan hal tersebut maka dirumuskan tujuan penelitian ini adalah untuk menghasilkan program baca tulis yang dapat diterapkan di sekolah dasar dengan kualifikasi layak dari segi kepraktisan, kemenarikan, dan kebermanfaatan dalam mengembangan kegiatan membaca dan menulis siswa.

\section{METODE}

Penelitian ini menggunakan rancangan penelitian pengembangan ADDIE yang terdiri dari lima tahap. Pertama tahap analyze, dilakukan analisis kebutuhan terhadap pelaksanaan kegiatan membaca dan menulis di sekolah. Kedua tahap design, dilakukan perancangan program membaca dan menulis yang akan diterapkan di sekolah berdasarkan hasil analisis kebutuhan pada tahap pertama. Ketiga tahap development, dilakukan pengembangan program dengan menyusun prosedur dan media untuk pelaksanaan penerapan program membaca dan menulis. Pada tahap implementation, dilakukan dengan menerapkan program yang telah disusun di sekolah secara langsung. Keempat tahap evaluation, dilakukan evaluasi terhadap seluruh tahap penelitian pengembangan program, ketercapaian tujuan pengembangan program, dan untuk kebutuhan perbaikan program sebagai produk yang dikembangkan.

Program membaca dan menulis diterapkan di kelas III SDN Karangbesuki 02 Kota Malang yang terdiri dari 19 siswa. Program diterapkan secara kolaboratif dengan guru kelas III SDN Karengbesuki 02 Kota Malang. Data hasil pengembangan produk dikumpulkan dengan instrumen angket untuk mengetahui respon siswa terhadap program yang dikembangkan, wawancara untuk mengetahui respon guru terhadap program yang dikembangkan, dan observasi untuk mengamati keterterapan program di sekolah. Data hasil pengembangan produk dianalisis dengan teknik analisis deskriptif kualitatif.

Fasilitas yang digunakan dalam penerapan program adalah papan tempel hasil karya untuk menyajikan hasil karya tulis siswa, papan penghargaan untuk memberikan reward pada siswa atas jumlah bacaan yang telah siswa baca dan tulis, dan buku bacaan anak yang digunakan sebagai media dalam kegiatan membaca dan menulis. Penyediaan fasilitas bertujuan untuk mendukung agar program di- 
terapkan dan menarik minat siswa dalam mengikuti kegiatan membaca dan menulis.

\section{HASIL}

\section{Deskripsi Produk}

Program membaca dan menulis yang dikembangkan dalam penelitian ini adalah program Baca Tulis Asik, Kreatif, dan Komunikatif yang disingkat menjadi Batu Akik. Program ini diarahkan untuk mendorong kemauan dan minat siswa untuk membaca dan menulis sehingga melalui program ini keterampilan siswa dalam membaca dan menulis dapat berkembang yang kemudian akan membantu siswa dalam proses belajar karena siswa mahir membaca dan menulis. Sesuai dengan judul program yakni baca tulis aktif karena pada program ini siswa dilatih dan dibiasakan untuk aktif membaca dan menulis pada jam khusus sesuai dengan penerapan program di sekolah. Baca tulis kreatif karena program ini akan dilaksanakan dengan kegiatan membaca dan menulis kreatif, dengan memanfaatkan berbagai bentuk wacana terutama bacaan sastra anak. Baca tulis komunikatif karena hasil karya siswa akan dipajang pada papan tempel yang telah disediakan sebagai bahan bacaan yang diharapkan dapat dimanfaatkan sebagai bahan bacaan siswa, selain itu guru juga diharapkan dapat memanfaatkan hasil tulisan siswa jika ada materi pembelajaran yang sesuai dengan hasil tulisan siswa.

Program ini dirancang secara dinamis yakni dapat diterapkan secara kondisional di sekolah yakni bukan untuk mengurangi esensi program namun menyesuaikan kondisi dan keadaan lapangan dengan adanya berbagai macam kegiatan di sekolah. Program ini dapat diterapkan secara kolaboratif dengan kegiatan pembelajaran, yakni siswa memilih bahan bacaannya secara mandiri yang sesuai dengan topik dan tugas proyek kelas sebagai media dalam kegiatan pembelajaran. Program ini juga dapat diterapkan secara mandiri di luar kegiatan pembelajaran, yakni pada jam khusus yang disediakan oleh sekolah untuk pengembangan kemampuan membaca dan menulis seperti pada jam kegiatan ekstrakurikuler sekolah di hari tertentu sehingga ada jam khusus yang difokuskan untuk pengembangan keterampilan membaca dan menulis.

Program baca tulis ini disusun dengan tujuan untuk mengembangkan keterampilan membaca dan menulis khusunya dalam hal kesadaran dan minat literasi sehingga siswa memiliki minat dalam kegiatan membaca dan semakin mahir dalam menulis. Pogram baca tulis ini dilaksanakan dengan memanfaatkan buku-buku bacaan sastra anak dan papan tempel untuk menyajikan hasil karya tulis siswa sebagai bentuk fasilitas untuk mendukung penerapan program. Langkah-langkah penerapan program Baca Tulis Asik, Kreatif, dan Komunikatif (Batu Akik) dirumuskan menjadi enam langkah dapat dilihat pada tabel 1 .

\section{Validasi Ahli Terhadap Rancangan Program Baca Tulis}

Validasi kepada ahli dilakukan untuk mengetahui kualifikasi produk yang meliputi kepraktisan, kemenarikan, dan kebermanfaatan sebagai program kegiatan membaca dan menulis di sekolah dasar. Hasil validasi ahli ditunjukkan pada tabel 2

Berdasarkan hasil respon siswa pada tabel 2, diketahui bahwa secara keseluruhan hasil validasi program yang dikembangkan mencapai kualifkasi baik dari segi kepraktisan, kemenarikan, dan kemudahan. Dari hasil validasi diperoleh saran perbaikan produk dari ahli. Dari segi kepraktisan program, untuk kegiatan menulis akan lebih baik jika disusun panduan untuk siswa menulis hasil kegiatan membaca sehingga siswa lebih mudah dalam mengorganisasikan ide menulisnya. Dari segi kemenarikan program, untuk bahan bacaan dapat lebih diberagamkan tidak hanya buku cerita namun bias berupa biografi, ensiklopedia anak-anak, atau komik edukatif. Sedangkan dari segi kebermanfaatan, untuk keberlanjutan penerapan program di sekolah hendaknya peneliti juga mensosialisaikan program pada tingkat kelas yang lain sehingga penerapan program dapat berjalan secara komprehensif di sekolah.

\section{Hasil Penerapan Program Baca Tulis}

Program baca tulis asik, kreatif, dan komunikatif (Batu Akik) diterapkan di kelas III SDN Karangbesuki 02 Kota Malang selama tiga kali pertemuan pada hari Sabtu pada jam sekolah pukul 07.00-08.30 WIB mulai tanggal 2 April 2016 hingga tanggal 16 April 2016. Pada pertemuan pertama, kegiatan baca tulis, guru memberikan motivasi pada siswa untuk membaca yakni dengan guru membacakan sebuah cerita di depan kelas kemudian melakukan tanya jawab membahas tentang hal-hal yang 
Tabel 1. Langkah Penerapan Program Batu Akik

\begin{tabular}{|c|c|}
\hline Langkah & Deskripsi \\
\hline 1 & $\begin{array}{l}\text { Siswa diberikan penjelasan tentang pelaksanaan kegiatan baca tulis yang akan dilakukan. Siswa } \\
\text { diberikan motivasi tentang manfaat baca tulis, pentingnya baca tulis, dan hal-hal menarik lainnya } \\
\text { baik berupa pertanyaan atau cerita singkat sehingga menumbuhkan minat dan keinginan siswa untuk } \\
\text { membaca dan menulis. }\end{array}$ \\
\hline 2 & $\begin{array}{l}\text { Siswa dengan bimbingan guru menentukan bahan bacaan yang akan dibaca seperti cerita tradisional, } \\
\text { cerita fiksi kontemporer, atau fabel. }\end{array}$ \\
\hline 3 & $\begin{array}{l}\text { Siswa membaca bahan bacaan yang dipilih secara mandiri. Guru berkeliling mengawasi, memfasili- } \\
\text { tasi dan melakukan penilaian terhadap keterampilan siswa dalam membaca, khususnya jika ada siswa } \\
\text { yang belum lancar membaca. }\end{array}$ \\
\hline 4 & $\begin{array}{l}\text { Setelah membaca siswa diminta membuat karya dari hasil bacaan yang telah dibacanya, yakni dengan } \\
\text { menceritakan kembali isi cerita yang dibaca atau siswa membuat cerita baru berdasarkan cerita yang } \\
\text { telah dibaca. Guru memberikan contoh bagaimana membuat karya tulis yang baik pada siswa. }\end{array}$ \\
\hline 5 & $\begin{array}{l}\text { Siswa menentukan kapan karya tulis akan dikumpulkan berdasarkan kesepakatan kelas dalam jangka } \\
\text { waktu satu minggu sehingga siswa dapat membaca satu buku dan menghasilkan satu karya tulis setiap } \\
\text { minggu. Siswa juga diberi kesempatan jika ingin membaca dan menulis lebih dari satu. }\end{array}$ \\
\hline 6 & $\begin{array}{l}\text { Siswa mengumpulkan karya tulis pada guru untuk dinilai dan dibenarkan jika ada penulisan yang } \\
\text { masih salah. Pada langkah ini guru melakukan penilaian terhadap keterampilan siswa dalam menulis. }\end{array}$ \\
\hline 7 & $\begin{array}{l}\text { Beberapa karya tulis siswa yang terpilih akan ditempelkan pada papan tempel yang telah disediakan } \\
\text { di kelas sebagai bentuk apresiasi karya siswa. Guru dapat melakukan pemasangan karya tulis secara } \\
\text { bergantian sehingga setiap siswa memperoleh kesempatan memajang karyanya. }\end{array}$ \\
\hline 8 & $\begin{array}{l}\text { Setiap kegiatan baca tulis yang dilakukan siswa diberikan penghargaan pada papan pengahargaan } \\
\text { (contoh: stiker bintang) yakni untuk setiap hasil karya tulis dari buku yang dibaca siswa. Di akhir bu- } \\
\text { lan, siswa yang paling banyak mengumpulkan bintang akan diberikan hadiah untuk memotivasi siswa } \\
\text { dalam membaca dan menulis. }\end{array}$ \\
\hline
\end{tabular}

Tabel 2. Validasi Ahli Terhadap Program Baca Tulis

\begin{tabular}{|c|c|c|c|c|}
\hline \multirow[t]{2}{*}{ No } & \multirow[t]{2}{*}{ Aspek } & \multirow[t]{2}{*}{ Indikator } & \multicolumn{2}{|r|}{ Hasil } \\
\hline & & & $\%$ & Kualifikasi \\
\hline 1. & Kepraktisan & $\begin{array}{l}\text { Kemudahan langkah-langkah kegiatan untuk siswa } \\
\text { Kejelasan petunjuk dan kegiatan untuk siswa } \\
\text { Kesesuaian waktu kegiatan dengan karakter siswa }\end{array}$ & 79 & Cukup Baik \\
\hline 2. & Kemenarikan & $\begin{array}{l}\text { Minat siswa dalam mengikuti kegiatan } \\
\text { Antusiasme siswa dalam mengikuti kegiatan }\end{array}$ & 76 & Cukup Baik \\
\hline 3. & Kebermanfaatan & $\begin{array}{l}\text { Kemampuan siswa dalam membaca dan menulis } \\
\text { Minat siswa dalam membaca dan menulis } \\
\text { Keterakaitan dengan mata pelajaran lain }\end{array}$ & 85 & Baik \\
\hline & & Rata-rata & 80 & Baik \\
\hline
\end{tabular}

ada pada cerita dan tentang kebiasaan baca tulis siswa yang ditujukan untuk memberikan motivasi dan mendorong siswa untuk terlibat aktif membaca serta menulis. Kegiatan dilanjutkan dengan siswa diminta memilih buku bacaan yang akan dibaca. Siswa terlihat antusias memilih buku bacaan yang akan dibaca. Selama membaca, ada beberapa siswa yang bertanya atau menjelaskan pada guru tentang cerita dalam buku bacaan yang dibaca. Seluruh siswa dalam kelas dapat membaca dengan baik, hanya ada dua siswa yang belum bisa lancar membaca sehingga membutuhkan bimbingan guru untuk dapat membaca. Setelah membaca siswa diminta menceritakan kembali isi cerita yang telah dibaca dengan bantuan pertanyaan $(5 \mathrm{~W}+1 \mathrm{H})$. Kegiatan siswa dalam membaca dan menulis dapat diamati pada gambar 1. 


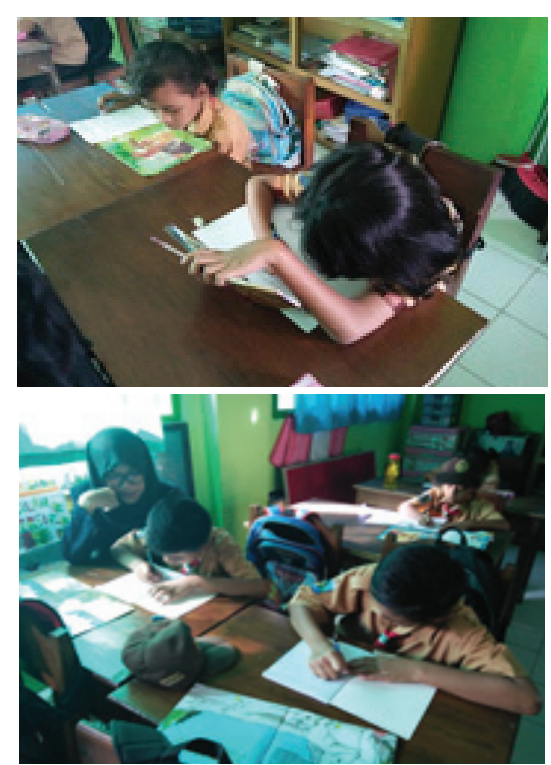

Gambar 1. Siswa Membaca Buku Cerita dan Menulis Kembali Cerita Yang Telah Dibaca

Pada gambar 1, guru memberikan bimbingan kepada siswa saat kegiatan membaca dan menulis cerita. Selama menulis banyak siswa yang masih kesulitan untuk menceritakan kembali cerita yang dibaca sehingga beberapa siswa hanya menyalin cerita yang dibaca. Dari hasil karya tulis siswa banyak siswa yang sering salah menggunakan huruf misal "b" dan "d" atau menggunakan kata yang kurang lengkap. Pada akhir pertemuan, rata-rata siswa belum menyelesaikan hasil karya tulisnya untuk menceritakan kembali. Siswa membuat kesepakatan dengan guru untuk menyelesaikan karya tulisnya pada pertemuan selanjutnya. Siswa diperkenankan membawa buku cerita yang telah dibaca.

Pada pertemuan kedua, kegiatan baca tulis, setelah membuka pelajaran, guru membagikan hasil karya tulis siswa yang telah dinilai. Siswa diminta mengamati hasil karya tulisnya yang telah ditandai jika ada kesalahan penulisan. Siswa diminta memperbaiki hasil tulisannya dan kemudian salah satu siswa diminta untuk membacakan hasil tulisannya di depan kelas. Di kelas ini terdapat satu siswa yang pandai bercerita dan sering mengikuti lomba bercerita, siswa ini diminta untuk membacakan karya tulis dengan tujuan untuk menarik minat dan perhatian siswa. Masuk pada langkah-langkah penerapan program, siswa dengan inisiatifnya sendiri segera mengambil buku bacaan yang telah disediakan di rak untuk dibaca. Siswa memilih buku cerita yang berbeda dengan cerita sebelumnya untuk di baca. Kegiatan pada tahap ini dapat diamati pada gambar 2.

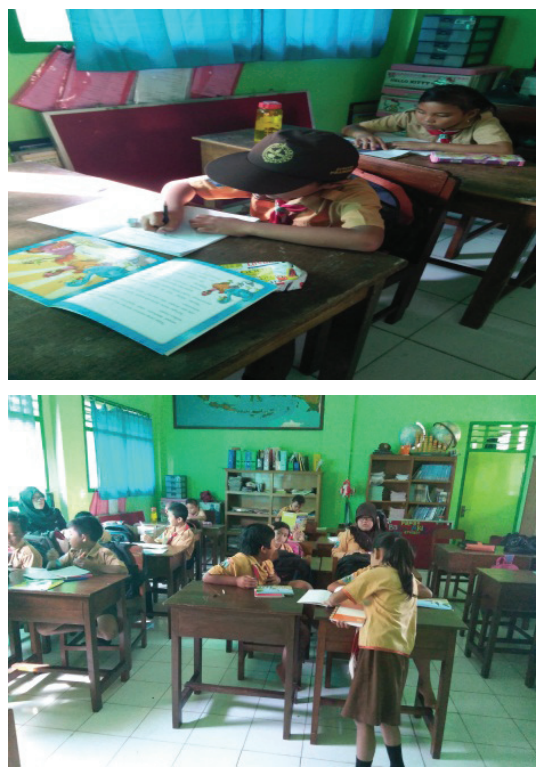

\section{Gambar 2. Siswa Melanjutkan Kegiatan Membaca dan Menulis Cerita}

Pada gambar 2, dapat diamati bahwa saat membaca siswa terlihat bercengkerama dengan teman sebangkunya membahas buku bacaan yang dibaca. Namun ada beberapa siswa yang juga tidak terlihat membaca meskipun telah mengambil buku bacaan dan melakukan aktivitas lain seperti menggambar, mengerjakan tugas dan bahkan menggangu temannya. Setelah selesai membaca, siswa membuat tulisan yakni pada pertemuan ini siswa diminta membuat cerita baru dengan tema yang sama pada cerita yang telah dibaca. Guru membimbing siswa tentang bagaimana membuat cerita baru yang baik dan benar dengan pemberian contoh. Pada akhir pertemuan, karena jam program telah selesai maka siswa berkesepakatan untuk menyelesaikan hasil karya tulisnya dan dikumpulkan pada pertemuan selanjutnya

Pada pertemuan ketiga, kegiatan baca tulis, berkaitan dengan tugas yang diberikan sebelumnya siswa mengumpulkan hasl karya tulisnya. Sebelum mengumpulkan karya tulisnya, menindak lanjuti tugas baca tulis pada pertemuan pertama siswa diminta untuk menuliskan kembali cerita pada kertas warna yang telah disediakan oleh guru yang kemudian akan ditempel di papan tempel Batu Akik. Siswa terlihat antusias saat menuliskan karya 
tulisnya pada kertas warna. Saat siswa menulis guru berkeliling menilai dan membimbing siswa. Untuk memberikan motivasi pada siswa, seluruh siswa diberi kesempatan untuk menempelkan karyanya pada papan tempel Batu Akik.

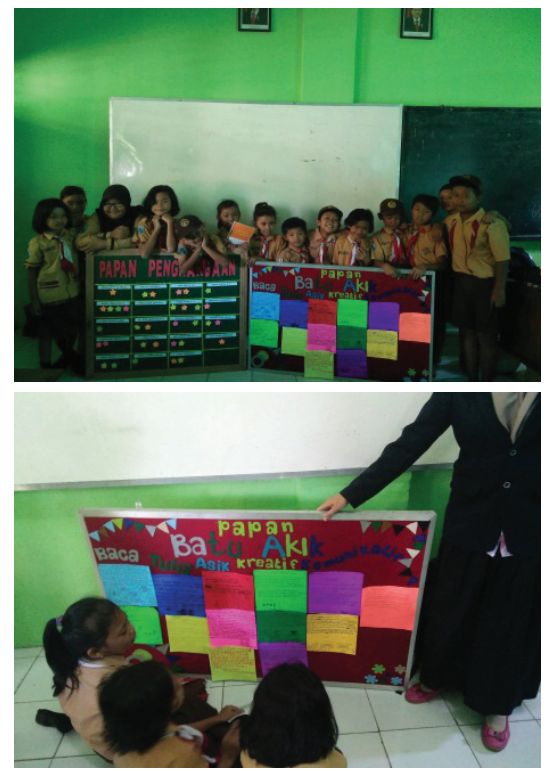

Gambar 3. Siswa Memajang Hasil Karya Tulisnya dan Mendapatkan Reward

Pada gambar 3, dapat diamati bahwa antusias dan senang saat menggunakan papan baca tulis sebagai media untuk memajang hasil karya tulsinya. Pada gambar kedua juga dapat diamati terdapat papan yang berisi tanda bintang. Tanda bintang ini diberikan oleh guru sebagai reward dan motivasi untuk siswa yang rajin dalam membaca buku yang dibuktikan dengan hasil tulisan. Selama tiga pertemuan ini siswa rata-rata mendapat dua tanda bintang karena telah membaca dan menulis pada pertemuan pertama dan kedua sebelumnya, ada pula siswa yang mendapat empat bintang karena telah membaca lebih banyak buku dan membuat tulisan di luar pertemuan, namun ada empat siswa yang hanya mendapatkan satu bintang karena hanya membaca satu buku. Pada akhir pertemuan, siswa diminta mengumpulkan karya tulis yang telah diperbaiki dan dipajang pada media papan temple di kelas.

\section{Respon Siswa dan Guru Terhadap Penerapan Program Baca Tulis}

Hasil respon siswa terhadap penerapan program baca tulis sebagai salah satu kegiatan di sekolah yang dikhusukan untuk kegiatan membaca dan menulis diketahui melalui pembagian angket pada siswa tentang kepraktisan, kemenarikan, dan kebermanfaatan kegiatan membaca dan menulis. Hasil respon siswa ditunjukkan pada tabel 3 .

Berdasarkan hasil respon siswa pada tabel 3, diketahui bahwa secara keseluruhan program yang dikembangkan mencapai kualifkasi baik dari segi kepraktisan, kemenarikan, dan kemudahan program. Selain respon siswa, dilakukan pula wawancara dengan guru kelas untuk mengetahui respon guru terhadap penerapan program Batu Akik dari segi kepraktisan, kemenarikan, dan kebermanfaatan program. Dari segi kepraktisan program, menurut guru program baca tulis ini mudah untuk diterapkan baik dari langkah-langkah dan kegiatannya di sekolah. Namun untuk alokasi waktu perlu lebih disesuaikan dengan kondisi kegiatan sekolah karena jam pembelajaran yang sudah penuh dan banyaknya kegiatan sekolah lain. Dari segi kemenarikan program, menurut guru program Batu Akik dapat menarik minat siswa jika diterapkan dengan baik dan berkelanjutan khusunya

Tabel 3. Respon Siswa Terhadap Program Batu Akik

\begin{tabular}{|c|c|c|c|c|}
\hline No & Aspek & Indikator & $\begin{array}{c}\text { Hasil } \\
\%\end{array}$ & Kualifikasi \\
\hline 1. & Kepraktisan & $\begin{array}{l}\text { Kemudahan langkah-langkah kegiatan untuk siswa } \\
\text { Kejelasan petunjuk dan kegiatan untuk siswa } \\
\text { Kesesuaian waktu kegiatan dengan karakter siswa }\end{array}$ & 78 & Cukup Baik \\
\hline 2. & Kemenarikan & $\begin{array}{l}\text { Minat siswa dalam mengikuti kegiatan } \\
\text { Antusiasme siswa dalam mengikuti kegiatan }\end{array}$ & 83 & Baik \\
\hline 3. & Kebermanfaatan & $\begin{array}{l}\text { Kemampuan siswa dalam membaca dan menulis } \\
\text { Minat siswa dalam membaca dan menulis } \\
\text { Keterakaitan dengan mata pelajaran lain }\end{array}$ & 80 & Baik \\
\hline & & Rata-rata & 80,3 & Baik \\
\hline
\end{tabular}


dengan adanya fasilitas yang mendukung program. Dari segi kebermanfaatan, menurut guru program ini diperlukan khususnya untuk melatih siswa yang masih kurang lancar dalam membaca dan menulis serta membantu siswa lain yang memiliki bakat dalam membaca dan menulis menjadi lebih baik.

\section{PEMBAHASAN}

Hasil penerapan program baca tulis menunjukkan bahwa pengembangan keterampilan membaca dan menulis dapat dilakukan dengan penyusunan dan penerapan sebuah program yang dapat diterapkan di sekolah. Program baca tulis yang dikembangkan memuat sekelompok aktivitas baca tulis yang dirancang untuk untuk meningkakan ketrampilan membaca, ketrampilan menulis, dan kemampuan literasi. Dari segi kepraktisan yakni program, langkah-langkah penerapan disusun sebagai proses yang dinamis, strategis, dan berorientasi pada tujuan. Penyusunan langkah penerapan ini didasarkan pada learning outcame sebagaimana pendapat Thomkins (2012:3) bahwa langkah yang dinamis akan lebih melibatkan keaktifan siswa, langkah yang strategis akan membuat siswa secara sadar memonitor pembelajaran yang mereka lakukan, serta beroriantasi pada tujuan sehingga siswa dapat menyusun rencana tentang apa yang dibaca dan apa yang ditulis oleh siswa. Untuk melengkapi kepraktisan produk, disusun panduan singkat penerapan program baca tulis dalam bentuk power point yang terdiri atas deskripsi program, tujuan, langkah penerapan, dan evaluasi program. Berikut tampilan cover ppt panduan penerapan program baca tulis asik, kretaif, dan komunikatif.

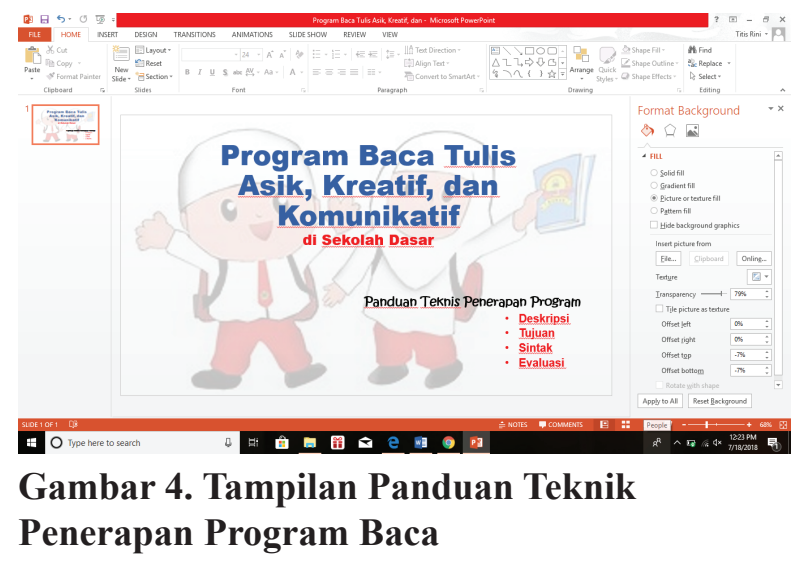

Selama penerapan diketahui bahwa masih ada beberapa siswa yang mengalami kesulitan dalam membaca dan menulis, hal ini menunjukkan bahwa program baca tulis memang perlu dikembangkan di sekolah dasar dan diterapkan di sekolah. Program baca tulis yang dikembangkan secara tidak langsung memberikan latihan pada siswa secara berkelanjutan untuk membaca dan menulis. Hal ini sesuai dengan pendapat Brown (2014) bahwa dalam melalui keterlibatan aktif siswa dalam proses membaca, siswa akan belajar menggunakan pengetahuan dan keterampilannya yang berkembangan untuk membangun fondasi yang kuat dalam perkembangan literasi. Berdasrkan hal tersebut, maka guru juga perlu mahir dalam memberikan pembelajaran membaca dan menulis, khususnya untuk menarik siswa dalam membaca dan menulis hingga idealnya siswa memiliki kesadaran dan kebiasaan yang baik dalam membaca dan menulis. Pada penerapan program guru dapat memberikan motivasi, menghadirkan topiktopik yang menarik, memberikan contoh yang tepat akan memfasilitasi siswa selama kegiatan program baca tulis.

Pengembangan keterampilan literasi ini yang kemudian dirancang dengan Project Based Learning (PjBL) untuk menciptaan lingkungan belajar yang mendorong kesadaran dan minat siswa dalam membaca dan menulis secara bertahap semakin meningkat. Untuk itu kegiatan membaca dan menulis dilaksanakan fleksibel dengan memberikan kesempatan pada siswa, yakni siswa diberikan kebebasan dalam menentukan topik dan merencanakan tugas membaca dan menulis. Hal ini disesuaikan dengan tujuan program yakni mendorong kemauan dan minat siswa untuk membaca dan menulis. Melalui program ini keterampilan siswa dalam membaca dan menulis dapat berkembang sehingga membantu siswa dalam proses belajar. Hal ini sesuai dengan hasil penelitian Bas \& Beyhan (2017) bahwa PjBL membantu siswa dalam mengembangkan keterampilan diri dimana siswa menggunakan berbagai jenis kecerdasan dalam menciptakan proyek. Khusus pada keterampilan literasi dalam program ini, keterampilan siswa difokuskan pada kreatifitas berfikir, pemecahan masalah, dan interaksi antar siswa dalam membaca dan menulis.

Pada penerapan program dimanfaatkan bahan bacaan anak sebagai media dalam membaca dan menulis. Pemanfaatan bahan bacaan sebagai media membaca dan menulis dalam program disesuaikan dengan pembelajaran Bahasa Indonesia di Sekolah Dasar. Pembelajaran membaca mencakup aspek menggunakan berbagai jenis membaca untuk me- 
mahami wacana berupa petunjuk, teks panjang, dan berbagai karya sastra untuk anak berbentuk puisi, dongeng, pantun, percakapan, cerita dan drama, sedangkan untuk pembelajaran menulis mencakup melakukan berbagai kegiatan menulis untuk mengungkapkan pikiran, perasaan, dan inormasi dalam untuk bentuk katangan sederhana, petunjuk, surat, pengumuman, dialog, formulir, teks pidato, laporan, ringkasan, parafrase, serta berbagai karya sastra untuk anak berbentuk cerita, puisi dan pantun (Gipayana, 2010: 39-40). Berdasarkan hal tersebut maka lebih lanjut, pada penerapan program ini dapat dikembangkan oleh guru dengan bahan bacaan yang berbeda seperti surat kabar atau majalah dimana siswa memiliki kebebasan dalam memilih apa yang diminati. Pemeberian variasi bacaan pada siswa seperti ini dapat mebuat karya tulis yang dibuat siswa menjadi lebih bervariasi.

Dari segi kemenarikan program Batu Akik yang dikembangkan, menunjukkan siswa cukup antusias dan memiliki minat dalam membaca dan menulis. Pada pertemuan kedua dan ketiga, sebelum diberi perintah untuk memulai kegiatan, siswa sacara langsung telah mengambil buku bacaannya dan memulai kegiatan membaca. Siswa juga sangat antuasis saat menuliskan hasil karyanya pada kertas warna yang disediakan dan menempelkannya pada papan yang telah disediakan. Rasa antusias ini menunjukkan ketercapaian program dalam hal kesadaran dan minat akan membaca dan menulisgan. Hal ini sesuai dengan hasil kajian Suyono (2007, 2009) bahwa penerapan program secara berkelanjutan mewujudkan sebuah masyarakat belajar (learning community) untuk waktu yang akan datang sehingga perlunya dikembangkan kesadaran, motivasi, keterampilan, dan kegemaran berliterasi di sekolah.

Dari segi kebermanfaatan, dalam penerapan program kegiatan dimulai dengan siswa membaca terlebih dahulu sebuah bahan bacaan kemudian siswa membuat tulisan tentang apa yang telah dibacanya. Kegiatan ini dapat diikuti siswa dengan baik, yakni dari hasil tulisan yang telah dibuat siswa menunjukkan siswa pemahaman terhadap apa yang dibacanya. Integrasi kegiatan membaca dan menulis tersebut pendapat Somadayo (2014:35-38) dan Budiyono (2012) membaca dan menulis memiliki sintaksis atau langkah-langkah pembelajaran tersendiri. Ada tahap pra, proses dan pasca mem- baca dan menulis yang terorganisir sehingga memudahkan ketika membaca dan menulis. Selaras dengan hal tersebut, penelitian sebelumnya oleh oleh Beck dan Jeffery (2009) mengemukakan bahwa genre bacaan dan materi yang diajarkan mempengaruhi pola berpikir siswa dalam menulis. Meskipun pembelajaran membaca dan menulis terintegrasi dan lintas kurikulum, namun bagaimana guru mengorganisasikan cara dan pola pikir siswa saat membaca dan menulis akan memudahkan siswa dalam mencari dan memahami informasi dalam membaca atau untuk menuangkan ide dan gagasan dalam menulis.

\section{SIMPULAN DAN SARAN}

\section{Simpulan}

Membaca dan menulis merupakan keterampilan berbahasa yang saling berkaitan melibatkan proses berpikir yakni membaca untuk memahami pesan dan menulis untuk menyampaikan pesan. Keterampilan membaca dan menulis perlu dikembangkan pada siswa mulai di sekolah dasar dalam pengembangan keterampilan literasi sejak dini. Pengembangan keterampilan tersebut dapat diwujudkan dengan pengembangan program baca tulis untuk menumbuhkan kesadaran dan minat akan pentingnya membaca dan menulis. Program baca tulis asik, kreatif, dan komunikatif dapat diterapkan di sekolah sebagai sebuah program yang dapat mengembangkan keterampilan membaca dan menulis. Hal ini didukung dengan hasil validasi program yang menunjukkan bahwa program layak untuk diterapkan dan respon positif dari siswa serta guru yakni dari segi kepraktisan, kemenarikan, dan kebermanfaatan program dalam kegiatan membaca dan menulis.

\section{Saran}

Secara keseluruhan, pengembangan program baca tulis ini dapat memberikan manfaat untuk siswa, guru, dan peneliti sendiri dalam mengembangkan keterampilan membaca dan menulis siswa di sekolah dasar. Program baca tulis ini disarankan agar diimplementasikan oleh sekolah sebagai bagian yang terintegrasi dengan program sekolah guna meningkatkan kualitas belajar siswa dalam membaca dan menulis sehingga dapat menumbuhkan kebiasaan literasi siswa. 


\section{DAFTAR RUJUKAN}

Ahmed, Y., Wagner, R. K., \& Lopez, D. 2014. Developmental Relations Between Reading And Writing At The Word, Sentence, And Text Levels: A Latent Change Score Analysis. Journal of Educational Psychology, 106(2), 419-434.

Bas, G., \& Beyhan, O. 2010. Effects Of Multiple Intelligences Supported Project-Based Learning On Students' Achievement Levels And Attitudes Towards English Lesson. International Electronic Journal of Elementary Education, 2(3).

Beck, S.W., \& Jeffery, J.V. 2009. Genre and Thinking in Academic Writing Tasks. Journal of Literacy Research, 41(2), 228-272.

Bilgin, M.I., Karakuyu, Y., \& Ay, Y. 2015. The Effects of Project Based Learning on Undergraduate Students' Achievement and Self Efficacy Beliefs Towards Science Teaching. Eurasia Journal of Mathematics, Science \& Technology Education, 11(3), 469-477.

Brown, C S. 2014. Language and Literacy Development in the Early Years: Foundational Skills that Support Emergent Readers. Journal of Language and Literacy Spectrum, 24 (1), 35 49. Dari https://eric.ed.gov/?id=EJ1034914.

Budiyono, H. 2012. Pembelajaran Keterampilan Menulis Berbasis Proses Menulis dan Teori Pemerolehan Bahasa. Jurnal PENA, 2(3).

Gipayana, M. 2009. Pengajaran Literasi Fokus Menulis di SD-MI. Malang: Asah Asih Asuh (A3).
Kemendikbud. 2016. Panduan Gerakan Literasi Sekolah di Sekolah Dasar. Jakarta: Direktorat Jenderal Pendidikan Dasar dan Menengah Kementerian Pendidikan dan Kebudayaan.

McDavid, J. C., \& Hawthorn, L. R. L. 2009. Program Evaluation \& Performance Measurement: An Introduction to Practice. Thousand Oaks, CA: Sage Publications Inc.

Sani, Ridwan A. 2013. Pembelajaran Saintifik untuk Implementasi Kurikulum 2013. Jakarta: Bumi Aksara

Somadayo, S. 2014. Strategi dan Teknik Pembelajaran Membaca. Yogyakarta: Graha Ilmu

Suryaman, M. 2011. Analisis Hasil Belajar Peserta Didik Dalam Literasi Membaca Melalui Studi Internasional (PIRLS) 2011. Jurnal LITERA, 14(1). Dari http://www.id.portalgaruda.org.

Suyono. 2007. Dimensi, Jenjang, dan Asesmen Perilaku Berliterasi Siswa di Sekolah. Jurnal Ilmu Pendidikan, 14(2), 69-75.

Suyono. 2009. Pembelajaran Efektif dan Produktif Berbasis Literasi: Analisis Konteks, Prinsip, dan Wujud Alternatif Strategi Implementasinya di Sekolah. Jurnal Bahasa dan Seni, 37(2), 203-217.

Thomkins, G. E. 2012. Third Edition Literacy in The Early Grades. United States of America: Pearson Education. 